\title{
THE IMPACT OF ACQUISITION ON STOCK VALUE IN CASE OF WARSAW STOCK EXCHANGE
}

\author{
Wojciech Kaczmarczyk ${ }^{1}$ \\ ${ }^{1}$ University of Economics in Katowice, 1 Maja street 50, 40-287 Katowice, Poland, \\ wojciech.kaczmarczyk@ue.katowice.pl,ORCID:0000-0003-2037-2568
}

\begin{abstract}
Research purpose: Seven of 10 companies that have won the Polish Forbes edition Merge \& Acquisition 2018 Ranking are listed on Warsaw Stock Exchange. The aim of the conducted research was to test if the biggest acquisitions have an impact on stocks value and is it possible for typical investor to create extra profit by using knowledge of acquisition based on public information.

Design/Methodology/Approach: Using data from Warsaw Stock Exchange (quotations), typical measures such as rate of return, standard deviation (risk), correlation and transaction volume changes were calculated. Each of the case results obtained for the company was compared with the result for stock market indexes: WIG (Warszawski Indeks Gietdowy - main WSE index), WIG20 (WSE sub-index of the 20 largest companies), mWIG40 (WSE sub-index of 40 medium companies) and sWIG80 (WSE sub-index of 80 small companies). In addition, the outcomes were confronted with public news (from WSE Electronic System for Information Transfer).

Findings: Conducted research has shown that generally successful finalisation of acquisition results in changes of stock prices behaviour. Unfortunately, observed reactions were not the same. Acquisitions induced both increases and decreases in stock prices; there was also no rule in case of risk change. Generally, acquisitions and merges had rather good influence in banking sector (which is still concentrating), but there was no common reaction in other sectors.

Originality/Value/Practical Implications: The results will be useful for investors acting on Warsaw Stock Exchange, especially for individual investor who are not able to carry out detailed analyses. The research provides results including possible pre-effects and after-effects of making big acquisition by a large company. The negative market reactions were also shown.
\end{abstract}

Keywords: Stock; Acquisition; Investments.

JEL codes: G11; G12; G34.

\section{Introduction}

The influence of information on asset's prices is an important issue for investors acting on stock exchanges, especially those who are focused on fundamental analysis methods (both in a classical and behavioural sense). It is well known that it is possible (and easy) to obtain enormous profits by using unpublic information (known only by insiders), but this kind of behaviour is illegal and unavailable for typical investors.

Therefore, investors are especially interested if it is also possible to gain an extraordinary profit by using just public information (published by the company or in press). Possibility of successful in using such information will be not only a great opportunity for the typical investor but also will prove that there is a lack of efficient on the capital market. Not so often the capital market in Poland provides data, which is useful whilst searching for a solution in this case.

Over the past years, the number of large mergers and acquisitions made by Polish enterprises has definitely increased. Most of them are listed on Warsaw Stock Exchange (WSE) - actually 7 of 10 companies from Polish Forbes edition Merge \& Acquisition 2018 are listed on WSE. The purpose of the research is to determine the impact of the acquisition process on stock quotes. In addition, the impact of acquisitions on the stock valuation in case of polish Stock Exchange is not well-described in the scientific literature. 
As it was mentioned above, the main aim of the research presented in this article was to test if the process of planned acquisition and its final realisation has a real and predictable impact on companies share's price. Three hypotheses were put forward: (1) there is a visible difference between share's prices behaviour before and after the acquisition, (2) influence of acquisition on share's prices is similar in case of all companies and (3) after publishing official information about finalising acquisition share's prices are averagely rising.

On the basis of share's closing prices (or index's closing values), quantitative methods were used, especially by computing measures such as logarithmical daily rate of return, standard deviation, Pearson correlation and average level of transaction volume. The results were calculated for the first day and then for 10th, 21st, 42nd and 126th days before and after acquisition periods (standard 2 weeks and 1, 2 and 6 months on WSE). The outcomes for companies were compared with WIG index and appropriate sub-indexes.

Conducted research had proven that there was a significant impact of announcing the acquisitions on share's values, but unfortunately, there were no typical pattern of observed changes. Consequently, research did not lead to finding any universal solution that can be applied by investors acting on Polish capital market but proved that not all kind of information is reflected in stock prices.

\section{Literature Review}

The problem of information impact on the stock exchange was described in detail by Fama in his Theory of Efficient Markets (1970). Generally, market can be characterised by strong, semi-strong and weak efficiency. On the strong efficient market, all kind of information (even unpublic) is fully reflected in assets pricing (Shefrin, 2005 cited in Zielonka, 2008, p. 32); on semi-strong efficient market, only public information is contained in share's price; and on weak efficient market, it is possible to gain extra profit even by using public information. The detailed history of efficient market theory was gathered by Sewell (2011).

Theoretical problems of market efficient and information impact are rather well described in Polish literature - especially by Zielonka $(2004,2008)$ or Babula and Blajer-Gołębiewska (2008) - but there is a visible need for practice works focused on Polish capital market (especially WSE).

It is necessary to mention further work of Blajer-Gołębiewska focused on the information asymmetry in corporate governance systems (2010), but research is focused on using information by listed companies, not by investors. Research made by Strzelczyk showed that transaction made by insiders had no visible impact on share's prices (2013). In addition, research conducted by Kaczmarczyk proved that acting on unpublic information by insiders was clearly visible in case of GetBack S.A. (2018).

Theoretical aspects of merges and acquisitions are also well described in Polish science, one of the newest is work made by Kozłowska-Makoś (2016), but the list of practical works is much shorter. Studies focused directly on the impact of fusions and acquisitions on share's prices were conducted by Czerwonka, who showed that, in short term, information about fusion averagely results in increasing of price but this the phenomenon is not visible in longer term (2010).

Maćkowiak was also analysing the impact of mergers and acquisitions on value of companies in Poland, but her work wasn't focused on share's price (2012). There is also an interesting work in which impact of mergers and acquisitions on share's price is checked in view of behavioural finance - as a result, higher impact was observed in case of nominally cheaper shares (Biegańska et al., 2016).

Kyriazopoulos (2016) analysed the impact of M\&A (Mergers and Acquisitions) taken in Eastern Europe in the banking sector both on stock of bidders and targets - about 23\% of the M\&A included in his research took place in Poland. As a result, it was found that above-average returns were achieved exclusively by objectives (application is for all the countries of Eastern Europe).

There are also a few actual works focused on the impact on acquired companies. Sharma and Raat (2016) focused on the impact of acquisitions of companies in Eastern Europe made by companies from Western Europe - an increase in the value of acquiring companies was noticed. Nowiński (2017) instead focused on the impact of acquisitions made by Polish companies abroad. His studies showed that the value of 
acquiring companies was in average increasing, especially in the case of companies that were making an international acquisition for the first time. Generally, similar results were obtained by Norbäck and Persson (2019) whose research was focused on acquisitions made by MNEs (MultiNational Enterprises) in emerging markets, but they additionally confirmed that there is a relationship between takeover risk and share price increase.

On the other hand, Asygnier (2018) focused on the impact of changing the company's name on the valuation of the company on WSE (change of name is often the result of a merger or acquisition). In average, the value was increasing before and falling after changing the name. Also, a study of the relation between block trades and stock prices proved that M\&A should potentially result in increasing stock value (Byrka-Kita et al. 2018).

\section{Methodology}

On the basis of the Polish Forbes edition Merge \& Acquisition 2018 Ranking (Karnaszewski, 2019) and official companies communicates (WSE Electronic System for Information Transfer), the list of biggest acquisitions taken by Polish companies listed on the WSE was specified. The day in which company published official information was chosen as the date of acquisitions.

Then quantitative methods were used. The complete database of stock exchange quotations from the analysed period was used (the entire population). On the basis of the closing prices, rates of return and typical measures were calculated for the following time periods:

- before and after 10 days from acquisition (standard 2 weeks on WSE),

- before and after 21 days from acquisition (standard month on WSE),

- before and after 42 days from acquisition (standard 2 months on WSE),

- before and after 126 days from acquisition (standard 6 months on WSE, calculations were made on 19 February 2019; therefore, in some cases, this period was ending on this date).

The logarithmic daily rate of return (1) was used basing on the following formula:

$$
r=\ln \left(\frac{P_{t+1}}{P_{t}}\right)
$$

where

$\mathrm{P}_{\mathrm{t}}$ is the price in first period;

$\mathrm{P}_{t+1}$ is the price in next period.

On the basis of the logarithmic daily rates of return, measures such as standard deviation (2) and Pearson correlation (3) with WIG index (it was assumed that there is a linear relationship between share's prices and index's values) were calculated. The Pearson correlation was calculated based on population (all events of the period), so it was not necessary to study its significance. Santander Bank and AmRest Holding were not quoted at every stock day, so correlations were calculated only for the rest of companies. Formulas are presented as follows:

where

$$
\sigma=\sqrt{\frac{\sum_{t=1}^{N}\left(r_{t}-r_{a}\right)^{2}}{N}}
$$

$\mathrm{N}$ is the population;

$\mathrm{r}_{\mathrm{t}}$ is the rate of return in $t$ period;

$r_{a}$ is the average rate of return.

$$
\rho_{12}=\frac{\left.\sum_{t=1}^{N}\left[r_{t 1}-\bar{r}_{t 1}\right]\left[r_{t 2}-\bar{r}_{t 2}\right)\right]}{\sqrt{\left.\sum_{t=1}^{N}\left[r_{t 1}-\bar{r}_{t 1}\right)\right]^{2} \sum_{t=1}^{N}\left[r_{t 2}-\bar{r}_{t 2}\right]^{2}}}
$$

where

$\mathrm{N}$ is the population;

$\mathrm{r}_{\mathrm{t} 1}$ is the rate of return of first asset in $t$ period;

$\mathrm{r}_{\mathrm{t} 2}$ is the rate of return of second asset in $t$ period;

$\bar{r}_{t 1}$ is the average rate of return of first asset in $t$ period;

$\bar{r}_{t 2}$ is the average rate of return of second asset in $t$ period. 
At least the average levels of transaction volume were calculated in every period for each company. The results obtained for companies were additionally compared with WIG index (in every case) and WIG20, mWIG40 and sWIG80 sub-indexes (companies were compared with appropriate sub-index), which limited the impact of the entire market on the result of research.

\section{Results}

As it was already mentioned, the study focused on companies that made the largest acquisitions in 2018 (based on Polish Forbes edition Merge \& Acquisition 2018). Basic information about them is presented in Table 1.

Table 1. Acquisition from Polish Forbes edition Merge \& Acquisition 2018 Ranking made by companies listed on Warsaw Stock Exchange (Source: author's own work based on Karnaszewski, 2018 and ESPI data)

\begin{tabular}{|c|c|c|c|c|}
\hline Rank & Company & Target & $\begin{array}{c}\text { Publication date } \\
\text { (finalising) }\end{array}$ & $\begin{array}{c}\text { Transaction } \\
\text { value (millions } \\
\text { PLN) }\end{array}$ \\
\hline 1 & PKN Orlen & Unipetrol & 1 October 2018 & 4,180 \\
\hline 2 & Bank BGŻ BNP Paribas & Raiffeisen Polbank & 10 April 2018 & 3,250 \\
\hline 3 & Bank Millennium & Eurobank & 5 November 2018 & 1,833 \\
\hline 5 & Santander Bank & Deutsche Bank Polska & 8 November 2018 & 1,290 \\
\hline 6 & Cyfrowy Polsat & Netia & 22 May 2018 & 1,277 \\
\hline 9 & AmRest Holdings & Sushi Shop Group & 27 July 2018 & 1,076 \\
\hline 10 & Grupa Azoty & COMPO Export & 6 September 2018 & 1,011 \\
\hline
\end{tabular}

Daily rates of return on day when information about acquisitions had been published (or in the case when it had been published after stock hours on next stock day) were in the range from $-5.75 \%$ (Grupa Azoty) to $1.67 \%$ (PKN Orlen), $-1.89 \%$ on an average. Positive rates of return were noticed only in case of PKN Orlen and Santander Bank (0.35\%).

Average transaction volume was calculated for every company in each time period. The results are shown in Table 2. In the case of Bank BGŻ BNP Paribas, which had rather very low liquidity, and AmRest Holdings, there was no noticeable impact of the acquisition on transaction volume (it was necessary to take into account split 1:10 made on 3 October 2018).

Table 2. Average daily transaction volume (number of shares sold) (Source: author's compilation)

\begin{tabular}{|l|c|c|c|c|c|c|c|}
\hline & PKN Orlen & $\begin{array}{c}\text { Bank BGŻ } \\
\text { BNP Paribas }\end{array}$ & $\begin{array}{c}\text { Bank } \\
\text { Millennium }\end{array}$ & $\begin{array}{c}\text { Santander } \\
\text { Bank }\end{array}$ & $\begin{array}{c}\text { Cyfrowy } \\
\text { Polsat }\end{array}$ & $\begin{array}{c}\text { AmRest } \\
\text { Holdings }\end{array}$ & Grupa Azoty \\
\hline \multicolumn{7}{|c|}{10 days } \\
\hline Before & $1,603,037$ & 65 & 620,221 & 1,285 & 488,072 & 9,525 & 57,425 \\
\hline After & 892,783 & 63 & $1,393,026$ & 308 & 675,223 & 9,552 & 106,766 \\
\hline \multicolumn{7}{|c|}{21 days } \\
\hline Before & $1,237,713$ & 65 & 588,853 & 884 & 422,695 & 6,562 & 54,557 \\
\hline After & 889,680 & 66 & $1,410,665$ & 220 & $1,019,229$ & 6,777 & 156,188 \\
\hline \multicolumn{7}{|c|}{42 days } \\
\hline Before & 966,618 & 65 & 934,142 & 558 & 453,866 & 7,812 & 43,813 \\
\hline After & 878,880 & 66 & $1,235,211$ & 336 & 737,088 & 11,193 & 185,490 \\
\hline \multicolumn{7}{|c|}{126 days } \\
\hline Before & 790,492 & 66 & 758,493 & 5,489 & 486,309 & 12,445 & 51,177 \\
\hline After & 864,289 & 57 & 955,690 & 773 & 554,753 & $10,710^{*}$ & 220,268 \\
\hline
\end{tabular}

* Calculation with splits included.

In case of PKN Orlen and Santander Bank, there was a noticeable increase in the transaction volume before finalising acquisitions (for Santander, it was 1,285 before versus 308 after the acquisition). Assets of Bank Millennium, Cyfrowy Polsat and Grupa Azoty were behaving in the opposite way - the daily transaction volume significantly increases after publishing information about taken acquisition. In the case of these companies, the impact of acquisition on the average volume was significantly visible. 
Pearson correlation values with WIG index were calculated only for 5 companies (Santander Bank and AmRest Holding had to low liquidity - transactions were not made on every stock day); the results are presented in Table 3.

Table 3. Values of Pearson correlation with WIG index (Source: author's compilation)

\begin{tabular}{|c|c|c|c|c|c|}
\hline & PKN Orlen & $\begin{array}{c}\text { Bank BGŻ } \\
\text { BNP Paribas }\end{array}$ & $\begin{array}{c}\text { Bank } \\
\text { Millennium } \\
\end{array}$ & $\begin{array}{c}\text { Cyfrowy } \\
\text { Polsat } \\
\end{array}$ & Grupa Azoty \\
\hline \multicolumn{6}{|c|}{10 days } \\
\hline Before & -0.045 & -0.033 & 0.627 & 0.066 & 0.424 \\
\hline After & 0.683 & 0.069 & 0.397 & 0.277 & 0.609 \\
\hline \multicolumn{6}{|r|}{21 days } \\
\hline Before & -0.109 & -0.302 & 0.608 & 0.159 & 0.461 \\
\hline After & 0.714 & -0.093 & 0.352 & 0.233 & 0.668 \\
\hline \multicolumn{6}{|r|}{42 days } \\
\hline Before & 0.226 & -0.034 & 0.573 & 0.201 & 0.356 \\
\hline After & 0.638 & -0.072 & 0.508 & 0.362 & 0.402 \\
\hline \multicolumn{6}{|r|}{126 days } \\
\hline Before & 0.535 & -0.040 & 0.610 & 0.249 & 0.331 \\
\hline After & 0.633 & 0.083 & 0.577 & 0.232 & 0.403 \\
\hline
\end{tabular}

In most cases, there was a clearly visible phenomenon of lower correlation values in time periods before than after acquisition, which was especially visible on PKN Orlen's assets. It needs to be highlighted that the WIG index portfolio in 9.29\% consists of PKN Orlen's shares, so negative values of correlation were not expected. The only exception was noticed in case of Bank Millennium where the correlation values were much higher during before periods. The phenomenon was noticeable particularly in 2-week and 1-month periods and was disappearing in the longest, 6-month period.

Computing average rates of return and standard deviations for each company brought more detailed data. The results calculated for PKN Orlen are presented in Table 4.

Table 4. Average daily rates of return and standard deviations - PKN Orlen (Source: author's compilation)

\begin{tabular}{|c|c|c|c|c|c|c|}
\hline & \multicolumn{2}{|c|}{ PKN Orlen } & \multicolumn{2}{|c|}{ WIG } & \multicolumn{2}{|c|}{ WIG20 } \\
\hline $\begin{array}{l}\text { Rate of return on the } \\
\text { first day }\end{array}$ & & $1.67 \%$ & & $-1.08 \%$ & & $-1.30 \%$ \\
\hline & average rate of return & standard deviation & average rate of return & standard deviation & average rate of return & standard deviation \\
\hline \multicolumn{7}{|c|}{10 days } \\
\hline before & $-0.18 \%$ & $1.80 \%$ & \begin{tabular}{|l|l|} 
& $0.43 \%$ \\
\end{tabular} & $0.59 \%$ & $0.42 \%$ & $0.62 \%$ \\
\hline after & $-0.54 \%$ & $2.13 \%$ & $\begin{array}{l:l} & -0.49 \% \\
\end{array}$ & $0.94 \%$ & $-0.52 \%$ & $1.19 \%$ \\
\hline \multicolumn{7}{|c|}{21 days } \\
\hline before & $0.10 \%$ & $1.80 \%$ & \begin{tabular}{l|l|} 
& $-0.14 \%$ \\
\end{tabular} & $0.83 \%$ & $-0.15 \%$ & $0.91 \%$ \\
\hline after & $-0.64 \%$ & $2.27 \%$ & $-0.43 \%$ & $0.97 \%$ & $-0.44 \%$ & $1.24 \%$ \\
\hline \multicolumn{7}{|c|}{42 days } \\
\hline before & $0.21 \%$ & $1.78 \%$ & \begin{tabular}{|l|l|} 
& $-0.00 \%$ \\
\end{tabular} & $0.93 \%$ & $0.02 \%$ & $1.13 \%$ \\
\hline after & $0.23 \%$ & $2.31 \%$ & \begin{tabular}{|l|l|} 
& $-0.05 \%$ \\
\end{tabular} & $1.10 \%$ & $-0.01 \%$ & $1.35 \%$ \\
\hline \multicolumn{7}{|c|}{126 days } \\
\hline before & $0.13 \%$ & $2.08 \%$ & \begin{tabular}{|l|l|} 
& $0.01 \%$ \\
\end{tabular} & $0.89 \%$ & $0.03 \%$ & $1.13 \%$ \\
\hline after & $-0.01 \%$ & $2.12 \%$ & $-0.00 \%$ & $1.03 \%$ & $0.00 \%$ & $1.23 \%$ \\
\hline
\end{tabular}

The acquisition had resulted in a positive rate of return on the first day (publication day) despite the whole market condition (both WIG and WIG20 indexes lost their value). Surprisingly, standard deviation had higher values in periods after acquisition (which seems to contradict the obtained correlation results). Visible grown of standard deviation in case of WIG index and WIG20 sub-index was in some part rather a result of high participation of PKN Orlen in their portfolio. Comparison with indexes shows that the acquisition had rather no impact on the average daily rates of return.

The results obtained for Bank BGŻ BNP Paribas are presented in Table 5. On the first day, price of BGŻ had decreased despite small growth visible on WSE indexes. Higher values of standard deviation were observed before finalising the acquisition. 
Table 5. Average daily rates of return and standard deviations - Bank BGŻ BNP Paribas (Source: author's compilation)

\begin{tabular}{|c|c|c|c|c|c|c|}
\hline & \multicolumn{2}{|c|}{ Bank BGŻ BNP Paribas } & \multicolumn{2}{|c|}{ WIG } & \multicolumn{2}{|c|}{ sWIG80 } \\
\hline $\begin{array}{l}\text { Rate of return on the } \\
\text { first day }\end{array}$ & & $-1.65 \%$ & & $0.27 \%$ & & $0.40 \%$ \\
\hline & average rate of return & standard deviation & average rate of return & standard deviation & average rate of return & standard deviation \\
\hline \multicolumn{7}{|c|}{10 days } \\
\hline before & $-0.58 \%$ & $2.22 \%$ & $-0.19 \%$ & $0.99 \%$ & $-0.05 \%$ & $0.54 \%$ \\
\hline after & $0.69 \%$ & $1.67 \%$ & $-0.03 \%$ & $0.52 \%$ & $-0.19 \%$ & $0.32 \%$ \\
\hline \multicolumn{7}{|c|}{21 days } \\
\hline before & $-0.52 \%$ & $1.99 \%$ & $-0.11 \%$ & $1.00 \%$ & $-0.03 \%$ & $0.46 \%$ \\
\hline after & $0.51 \%$ & $1.45 \%$ & $0.08 \%$ & $0.74 \%$ & $-0.11 \%$ & $0.41 \%$ \\
\hline \multicolumn{7}{|c|}{42 days } \\
\hline before & $-0.22 \%$ & $2.32 \%$ & $-0.19 \%$ & $1.02 \%$ & $-0.07 \%$ & $0.64 \%$ \\
\hline after & $0.11 \%$ & $1.25 \%$ & $-0.03 \%$ & $0.80 \%$ & $-0.13 \%$ & $0.43 \%$ \\
\hline \multicolumn{7}{|c|}{126 days } \\
\hline before & $-0.07 \%$ & $1.94 \%$ & $-0.06 \%$ & $0.83 \%$ & $-0.03 \%$ & $0.56 \%$ \\
\hline after & $-0.22 \%$ & $3.04 \%$ & $-0.02 \%$ & $0.88 \%$ & $-0.18 \%$ & $0.55 \%$ \\
\hline
\end{tabular}

In addition, after acquisition, the average daily rates of return had increased, especially during the first month after the information was published (from $-0.58 \%$ to $0.69 \%$ in 2 -week period and from -0.52 to $0.51 \%$ in 1 -month period) whilst sub-index sWIG80 had lost its value. The observed effect had ended in longest period (average rates of return had fallen and standard deviation had increased).

Data computed in case of Bank Millennium are presented in Table 6. Prices of Millennium's assets behaved in a similar way as in case of BGŻ. On the first day, rate of return was negative in contrast to changes observed in case of WSE indexes. The average daily rates of return were significantly higher in after acquisition time periods (change from $-0.14 \%$ to $0.45 \%$ per day in 2 -week period). There was no visible trend in changing of standard deviation's value (increase in 2-week period and decrease in 1month period).

Table 6. Average daily rates of return and standard deviations - Bank Millennium (Source: author's compilation)

\begin{tabular}{|c|c|c|c|c|c|c|}
\hline & \multicolumn{2}{|c|}{ Bank Millennium } & \multicolumn{2}{|c|}{ WIG } & \multicolumn{2}{|c|}{ mWIG40 } \\
\hline $\begin{array}{l}\text { Rate of return on the } \\
\text { first day }\end{array}$ & & $-0.57 \%$ & & $1.20 \%$ & & $0.32 \%$ \\
\hline \multicolumn{7}{|c|}{10 days } \\
\hline before & $-0.14 \%$ & $1.76 \%$ & \begin{tabular}{l|l|}
$-0.09 \%$ \\
\end{tabular} & $1.14 \%$ & $-0.34 \%$ & $0.88 \%$ \\
\hline after & $0.45 \%$ & $2.60 \%$ & $-0.18 \%$ & $1.01 \%$ & $-0.23 \%$ & $0.86 \%$ \\
\hline before & $-0.16 \%$ & $1.56 \%$ & $-0.20 \%$ & $1.13 \%$ & $-0.32 \%$ & $0.83 \%$ \\
\hline after & $0.27 \%$ & $1.04 \%$ & $0.27 \%$ & $1.07 \%$ & $0.23 \%$ & $0.97 \%$ \\
\hline \multicolumn{7}{|c|}{42 days } \\
\hline before & $-0.04 \%$ & $2.07 \%$ & $-0.16 \%$ & $1.00 \%$ & $-0.19 \%$ & $0.95 \%$ \\
\hline after & $0.04 \%$ & $2.16 \%$ & $0.12 \%$ & $1.15 \%$ & $0.09 \%$ & $0.93 \%$ \\
\hline
\end{tabular}

The results calculated for Santander Bank are presented in Table 7. Unlike the previous banks, Santander's assets had a small increase in price on the first day but were losing value in 2-week, 1month and 2-month periods (decrease in the value were stronger than in case of WIG and WIG20 indexes). In the long term, standard deviation decreased (which did not change for WIG and increased for WIG20). 
Table 7. Average daily rates of return and standard deviations - Santander Bank (Source: author's compilation)

\begin{tabular}{|c|c|c|c|c|c|c|}
\hline & \multicolumn{2}{|c|}{ Santander Bank } & \multicolumn{2}{|c|}{ WIG } & \multicolumn{2}{|c|}{ WIG20 } \\
\hline $\begin{array}{l}\text { Rate of return on the } \\
\text { first day }\end{array}$ & & $0.35 \%$ & & $-1.27 \%$ & & $-1.79 \%$ \\
\hline & average rate of return & standard deviation & average rate of return & standard deviation & average rate of return & standard deviation \\
\hline \multicolumn{7}{|c|}{10 days } \\
\hline before & $0.59 \%$ & $3.05 \%$ & \begin{tabular}{|l|l|} 
& $0.11 \%$ \\
\end{tabular} & $0.69 \%$ & $0.02 \%$ & $0.70 \%$ \\
\hline after & $-0.97 \%$ & $3.46 \%$ & $-0.38 \%$ & $0.76 \%$ & $-0.29 \%$ & $1.36 \%$ \\
\hline \multicolumn{7}{|c|}{21 days } \\
\hline before & $0.14 \%$ & $4.89 \%$ & \begin{tabular}{l|l|} 
& $0.05 \%$ \\
\end{tabular} & $0.94 \%$ & $-0.06 \%$ & $0.86 \%$ \\
\hline after & $-0.38 \%$ & $4.10 \%$ & $-0.22 \%$ & $0.86 \%$ & $0.02 \%$ & $1.49 \%$ \\
\hline \multicolumn{7}{|c|}{42 days } \\
\hline before & $-0.07 \%$ & $4.71 \%$ & \begin{tabular}{l|l|} 
& $-0.10 \%$ \\
\end{tabular} & $0.88 \%$ & $-0.03 \%$ & $1.11 \%$ \\
\hline after & $-0.40 \%$ & $3.67 \%$ & \begin{tabular}{|l|l|} 
& $-0.07 \%$ \\
\end{tabular} & $0.95 \%$ & $0.02 \%$ & $1.41 \%$ \\
\hline \multicolumn{7}{|c|}{126 days } \\
\hline before & $-0.15 \%$ & $3.87 \%$ & \begin{tabular}{|l|l|} 
& $-0.09 \%$ \\
\end{tabular} & $0.78 \%$ & $0.01 \%$ & $1.10 \%$ \\
\hline after & $-0.13 \%$ & $2.69 \%$ & $-0.01 \%$ & $0.88 \%$ & $0.03 \%$ & $1.26 \%$ \\
\hline
\end{tabular}

Data for Cyfrowy Polsat are presented in Table 8. On the first day, Polsat's assets had lost $2.54 \%$ of their value.

Table 8. Average daily rates of return and standard deviations - Cyfrowy Polsat (Source: author's compilation)

\begin{tabular}{|c|c|c|c|c|c|c|}
\hline & \multicolumn{2}{|c|}{ Cyfrowy Polsat } & \multicolumn{2}{|c|}{ WIG } & \multicolumn{2}{|c|}{ WIG20 } \\
\hline $\begin{array}{l}\text { Rate of return on the } \\
\text { first day }\end{array}$ & & $-2.54 \%$ & & $-0.54 \%$ & & $-0.87 \%$ \\
\hline & average rate of return & standard deviation & average rate of return & standard deviation & average rate of return & standard deviation \\
\hline \multicolumn{7}{|c|}{10 days } \\
\hline before & $0.01 \%$ & $2.55 \%$ & \begin{tabular}{|l|l|} 
& $0.07 \%$ \\
\end{tabular} & $0.93 \%$ & $0.14 \%$ & $1.22 \%$ \\
\hline after & $-0.20 \%$ & $1.72 \%$ & $-0.04 \%$ & $0.88 \%$ & $-0.05 \%$ & $1.18 \%$ \\
\hline \multicolumn{7}{|c|}{21 days } \\
\hline before & $-0.00 \%$ & $2.36 \%$ & $-0.07 \%$ & $0.85 \%$ & $-0.08 \%$ & $1.13 \%$ \\
\hline after & $-0.56 \%$ & $2.42 \%$ & $-0.23 \%$ & $0.93 \%$ & $-0.24 \%$ & $1.16 \%$ \\
\hline \multicolumn{7}{|c|}{42 days } \\
\hline before & $0.09 \%$ & $1.94 \%$ & \begin{tabular}{l|l|} 
& $-0.07 \%$ \\
\end{tabular} & $0.90 \%$ & $-0.05 \%$ & $1.18 \%$ \\
\hline after & $-0.17 \%$ & $2.04 \%$ & $-0.08 \%$ & $0.87 \%$ & $-0.09 \%$ & $1.11 \%$ \\
\hline \multicolumn{7}{|c|}{126 days } \\
\hline before & $0.03 \%$ & $1.58 \%$ & \begin{tabular}{|l|l|} 
& $-0.05 \%$ \\
\end{tabular} & $0.85 \%$ & $-0.06 \%$ & $1.08 \%$ \\
\hline after & $-0.15 \%$ & $1.74 \%$ & $-0.06 \%$ & $0.96 \%$ & $-0.04 \%$ & $1.19 \%$ \\
\hline
\end{tabular}

In addition, average daily rates of return were a bit lower in after the acquisition periods (the observed difference is higher than in case of WIG and WIG20 indexes). Visible changes in standard deviation's value were observed only between before and after acquisition in 2-week period (there was no visible change in further periods).

A significant drop was noticed in case of AmRest Holding (data were presented in Table 9) on the first day when daily rate of return was equal to $-4.78 \%$. Average daily rates of return were lower in after periods, but values of WSE indexes were behaving in the same way. There was no visible rule in changes of standard deviation's value. 
Table 9. Average daily rates of return and standard deviations - AmRest Holdings (Source: author's compilation)

\begin{tabular}{|c|c|c|c|c|c|c|}
\hline & \multicolumn{2}{|c|}{ AmRest Holdings } & \multicolumn{2}{|c|}{ WIG } & \multicolumn{2}{|c|}{ mWIG40 } \\
\hline $\begin{array}{l}\text { Rate of return on the } \\
\text { first day }\end{array}$ & & $-4.78 \%$ & & $-0.37 \%$ & & $-0.04 \%$ \\
\hline & average rate of return & standard deviation & average rate of return & standard deviation & average rate of return & standard deviation \\
\hline \multicolumn{7}{|c|}{10 days } \\
\hline before & $0.04 \%$ & $2.21 \%$ & \begin{tabular}{|l|l|}
$0.52 \%$ \\
\end{tabular} & $0.67 \%$ & $0.25 \%$ & $0.37 \%$ \\
\hline after & $-0.31 \%$ & $2.06 \%$ & $-0.17 \%$ & $1.03 \%$ & $-0.08 \%$ & $0.77 \%$ \\
\hline \multicolumn{7}{|c|}{21 days } \\
\hline before & $0.05 \%$ & $2.15 \%$ & \begin{tabular}{|l|l|}
$0.28 \%$ \\
\end{tabular} & $0.86 \%$ & $0.09 \%$ & $0.67 \%$ \\
\hline after & $-0.24 \%$ & $1.53 \%$ & $0.12 \%$ & $0.99 \%$ & $-0.02 \%$ & $0.65 \%$ \\
\hline \multicolumn{7}{|c|}{42 days } \\
\hline before & $-0.00 \%$ & $2.13 \%$ & $0.06 \%$ & $0.90 \%$ & $-0.08 \%$ & $0.74 \%$ \\
\hline after & $0.01 \%$ & $2.67 \%$ & $-0.02 \%$ & $0.93 \%$ & $-0.07 \%$ & $0.89 \%$ \\
\hline \multicolumn{7}{|c|}{126 days } \\
\hline before & $0.02 \%$ & $2.38 \%$ & $-0.09 \%$ & $0.91 \%$ & $-0.13 \%$ & $0.76 \%$ \\
\hline after & $-0.11 \%$ & $2.68 \%$ & $0.01 \%$ & $1.02 \%$ & $-0.05 \%$ & $0.88 \%$ \\
\hline
\end{tabular}

Even higher drop was observed on the first day in case of Grupa Azoty (results are presented in Table 10). In addition, average daily rates of return were much lower after acquisition (which was not observed in case of WSE indexes). Values of standard deviation had also significantly risen in after acquisition periods (which was again not observed whilst analysing WIG and mWIG40 indexes).

Table 10. Average daily rates of return and standard deviations - Grupa Azoty (Source: author's compilation)

\begin{tabular}{|c|c|c|c|c|c|c|}
\hline & \multicolumn{2}{|c|}{ Grupa Azoty } & \multicolumn{2}{|c|}{ WIG } & \multicolumn{2}{|c|}{ mWIG40 } \\
\hline $\begin{array}{l}\text { Rate of return on the } \\
\text { first day }\end{array}$ & & $-5.73 \%$ & & $-0.45 \%$ & & $-1.17 \%$ \\
\hline & average rate of return & standard deviation & average rate of return & standard deviation & average rate of return & standard deviation \\
\hline \multicolumn{7}{|c|}{10 days } \\
\hline before & $-0.16 \%$ & $1.87 \%$ & $-0.08 \%$ & $0.96 \%$ & $-0.40 \%$ & $0.76 \%$ \\
\hline after & $-1.32 \%$ & $4.34 \%$ & \begin{tabular}{|l|l|} 
& $-0.08 \%$ \\
\end{tabular} & $0.88 \%$ & $-0.01 \%$ & $1.14 \%$ \\
\hline \multicolumn{7}{|c|}{21 days } \\
\hline before & $-0.63 \%$ & $2.60 \%$ & \begin{tabular}{l|l|} 
& $-0.07 \%$ \\
\end{tabular} & $1.03 \%$ & $-0.27 \%$ & $0.76 \%$ \\
\hline after & $-1.23 \%$ & $3.75 \%$ & $\mid-0.02 \%$ & $0.77 \%$ & $0.05 \%$ & $0.94 \%$ \\
\hline \multicolumn{7}{|c|}{42 days } \\
\hline before & $-0.40 \%$ & $2.22 \%$ & \begin{tabular}{|l|l|}
$0.08 \%$ \\
\end{tabular} & $0.92 \%$ & $-0.10 \%$ & $0.71 \%$ \\
\hline after & $-0.88 \%$ & $3.76 \%$ & \begin{tabular}{|l|l|} 
& $-0.07 \%$ \\
\end{tabular} & $0.98 \%$ & $-0.10 \%$ & $0.91 \%$ \\
\hline \multicolumn{7}{|c|}{126 days } \\
\hline before & $-0.33 \%$ & $2.44 \%$ & \begin{tabular}{|l|l|} 
& $-0.02 \%$ \\
\end{tabular} & $0.91 \%$ & $-0.11 \%$ & $0.74 \%$ \\
\hline after & $0.20 \%$ & $3.52 \%$ & $0.01 \%$ & $1.00 \%$ & $0.00 \%$ & $0.89 \%$ \\
\hline
\end{tabular}

Data presented above show that there was no universal rule for change in the prices after finalising acquisition process. Only in the case of 2 companies, constant grown of their values in after periods was observed (Bank BGŻ BNP Paribas and Millennium Bank). There was also no common behaviour in case of standard deviation's changes.

Gathered data and obtained results turned out to be sufficient to verify all hypotheses. Observed changes in transaction volume level, correlation strength, daily rates of return and standard deviation's values had clearly showed that there is a visible difference between share's prices behaviour before and after the acquisition, so the first hypothesis was verified as true. Moreover, observed changes indicate that the WSE is not a strong efficient market (within meaning of the Fama's theory) - visible movements prove that not all information was included in stock's prices.

Unfortunately, there was no typical rule for observed changes. Companies were acting similarly only in case of changes in the strength of correlation with WSE main index - WIG. For other measures, it was impossible to recognise any kind of pattern. For this reason, the second hypothesis was verified as false - in the case of each company, different reactions were observed. 
In addition, share's prices were falling after acquisitions in most of the analysed cases (small increases were observed only in case of two banks, maybe because bank sector in Poland is still concentrating), so the third hypothesis also had to be generally verified as false.

\section{Conclusions}

Conducted research showed that there is a relationship between acquisitions and stock's prices, but it is impossible to make extraordinary profit based only on official information about acquisition - even in the case of the biggest companies. The increase in the value of the company after the acquisition, observed in earlier studies, did not occur, which may be related to the size of the companies and transactions. Investors still need to use much more complex analytical tools. On the other hand, research had proven that WSE is not a strong efficient market, because visible differences and changes show that not all information was fully reflected in prices. The above means that searching for methods of using public information is still an interesting topic of research.

Presented data and conclusions can be used by both companies and investors acting on the WSE. It will be potentially useful to expand research by detailed analysis of all official company's statements and press news, which can bring additional explanation of observed phenomena and noticed differences (differences may depend, to a large extent, on the information policy of the analysed companies). In addition, further research may focus only on the analysis of banking sector companies listed on WSE. This direction of research is also justified by the consolidation of the banking sector currently on going in Poland.

\section{References}

Asygnier, R. (2018). Does the change in the company's name affect the share price? The case study of the Polish capital market, Journal of Economics and Management, (2), 18-29.

Babula, E., \& Blajer-Gołębiewska, A. (2008). Wpływ informacji na zachowania podmiotów na rynkach akcji. In G. Maniak ed. 2008. Problemy ekonomii i polityki gospodarczej, Szczecin: Wydawnictwo Katedry Mikroekonomii Uniwersytetu Szczecińskiego.

Biegańska, K., Jasiniak, M., Pastusiak, R., \& Pluskota, A. (2016). Efekt zakotwiczenia w transakcjach fuzji i przejęć na przykładzie Polski, Finanse, Rynki Finansowe, Ubezpieczenia, (1), 585-593.

Blajer-Gołębiewska, A. (2010). Asymetria informacji w systemach nadzoru korporacyjnego na przykładzie polskich spótek giełdowych. In D. Kopycińska ed. 2010. Problemy gospodarowania w Polsce, Szczecin: Wydawnictwo Katedry Mikroekonomii Uniwersytetu Szczecińskiego.

Byrka-Kita, K., Czerwiński, M. \& Preś-Perepeczo, A. (2018) What Drives Shareholder Reaction and Wealth Effect in Block Trades? Evidence from the Warsaw Stock Exchange, Emerging Markets Finance \& Trade, (54), 1586-1607.

Czerwonka, L. (2010). Wpływ fuzji przedsiębiorstw na ich wartość, Ekonomika i Organizacja Przedsiębiorstwa, (4), 31-37.

Fama, E. (1970). Efficient Capital Markets: A Review of Theory and Empirical Evidence. Journal of Finance, (25), 383-416.

Kaczmarczyk, W. (2018). Information asymmetry risk on Polish Stock Exchange on example of GetBack S.A. In Managing and Modelling of Financial Risks, 9th International Scientific Conference, Conference proceedings, 205-212.

Karnaszewski., P. (2019). Polskie firmy ruszyły na łowy za granicą, Forbes, (2), 74-81.

Kozłowska-Makoś, D. (2016). Fuzje i przejęcia jako formy koncentracji kapitału, Studia Ekonomiczne. Zeszyty Naukowe Uniwersytetu Ekonomicznego w Katowicach, (282), 69-79.

Kyriazopoulos, G. (2016). Wealth Effects from Banks Mergers and Acquisitions in Eastern Europe. International Journal of Economics and Finance Issues, (2), 588-595.

Maćkowiak, E. (2012). Fuzje i przejęcia w kreowaniu wartości przedsiębiorstwa. Zeszyty Naukowe Uniwersytetu Szczecińskiego, Finanse, Rynki Finansowe, Ubezpieczenia, (56), 119-135. 
Norbäck, P., Persson, L. (2019). Stock Market Impact of Cross-Border Acquisitions in Emerging Markets, The North American Journal of Economics and Finance, (48), 346-363.

Nowiński, W. (2017). International acquisitions by Polish MNEs. Value creation or destruction? European Business Review, (2), 205-2018.

Official communicates of companies listed on Warsaw Stock Exchange. [Accessed 30.03.2019]. Available from Internet: https://www.bankier.pl/gielda/wiadomosci/komunikaty-spolek

Sewell., M. (2011). History of the Efficient Market Hypothesis. [Accessed 30.03.2019]. Available from Internet: https://www.gyc.com.sg/files/p_sewell-history.pdf

Sharma, A., Raat, E. (2016). Acquiring control in emerging markets: Foreign acquisitions in Eastern Europe and the effect on shareholder wealth. Research in International Business and Finance, (37), 153-169.

Strzelczyk, A. (2013). Transakcje insiderów a ceny akcji spółek notowanych na Giełdzie Papierów Wartościowych w Warszawie S.A. Zarządzanie i Finanse, (3), 79-87.

Zielonka, P. (2004). Behawioralne finanse. In T. Tyszka, ed. 2004. Psychologia ekonomiczna, Gdańsk: Gdańskie Wydawnictwo Psychologiczne.

Zielonka, P. (2008). Behawioralne aspekty inwestowania na rynku papierów wartościowych, 2nd ed., Warsaw: CeDeWu. 